\title{
Estimation of Deterioration Aspects of Granitic Columns at the Mosque of Al-Nasir Mohamed Ibn Qalawun, Cairo, Egypt
}

Fatma M. Helmi ${ }^{\mathrm{a}}$, Yasser K. Hefni ${ }^{\mathrm{b}}$ *

a. Conservation Department, Faculty of Archaeology, Cairo University, 12613 Giza, Egypt.

b. Conservation Dept, Faculty of Archaeology and Tourism Guidance, Misr University for Science \& Technology, Egypt.

\section{HIGHLIGHTS}

- Investigation of granitic columns and their deterioration aspects.

- Characterization of physiochemical and mechanical weathering processes.

- Estimation of weathered granite porosity.

- Identification of microbiological colonization.

- Determination of the inappropriate resinous material.

\section{ARTICLE INFO}

\section{Article History:}

Received: 7 June 2020

Revised: 31 July 2020

Accepted: 6 September 2020

Available online: 7 September 2020

Keywords:

Granitic columns, Weathering, Mineralogical alteration, Fault restoration, Specific surface area.

\footnotetext{
* Corresponding author: yasser.shahin240@yahoo.com
}

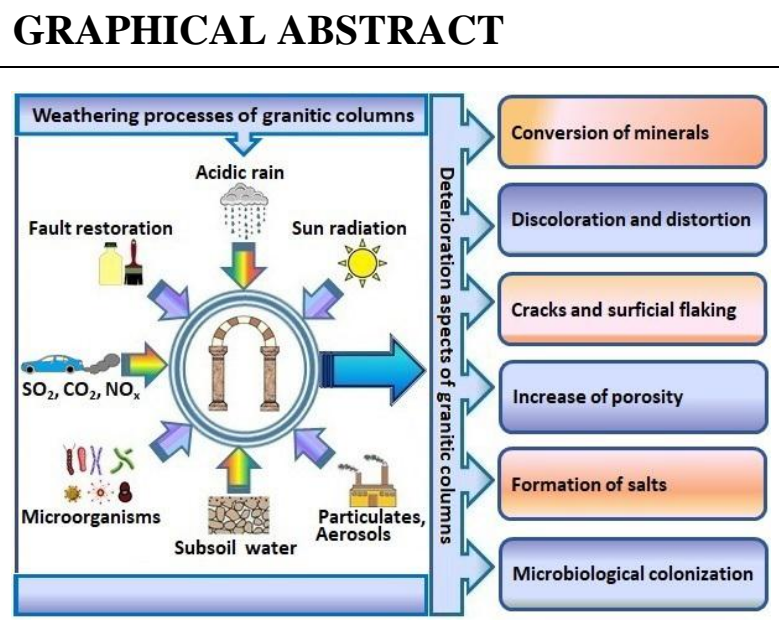

\begin{abstract}
The mosque of Al-Nasir Mohammad Ibn Qalawun represents one of the important and high valuable Mamluk mosques in Egypt. The granitic columns used in this mosque provide a significant case of reusing the architectural elements dated back to the earlier Pharaonic constructions. These granitic columns have been exposed to aggressive physiochemical and mechanical weathering processes. Moreover, they have been subjected to faulty restoration with an inappropriate resinous material which led to many deterioration aspects.
\end{abstract}


The current study aims to assess the state of granitic columns and to characterize their deterioration aspects. Examinations and analytical study were carried out using stereomicroscope (SM), scanning electron microscope (SEM), polarized light microscope (PLM), X-ray diffraction analysis (XRD), energy dispersive spectrometer (EDS), Brunauer-Emmett-Teller surface area (BET), Raman spectroscopy (RS), in addition to microbiological investigation. The data declared conversion of mineralogical composition, discoloration, poor aesthetic properties, increase of porosity, cracks, surficial flaking, salt crystallization and microbiological colonization. Hence, it is crucial to conduct conservation of the studied granitic columns.

\section{Introduction}

Mosques and other architectural buildings represent the most important surviving Mamluk monuments in Egypt. The mosque of Al-Nasir Mohammad Ibn Qalawun (Fig. 1) is considered a high valuable Mamluk mosque, as it still contains numerous architectural elements from the time of its earlier foundation. It was constructed by Al-Nasir Mohammad Ibn Qalawun, the ninth Bahri Mamluk sultan of Egypt [1, 2].

Unlike the complex of Al-Nasir Mohammad constructed in Al-Muizz street, this mosque was built inside the citadel of Saladin at Cairo, Egypt (Fig. 2). It is located in the south-western part of the citadel in a distinct site, facing the mosque of Mohammad Ali which was built during the later Ottoman period [3]. The mosque followed the hypostyle design, in which the plan is composed of an open courtyard surrounded by four riwaqs that were constructed using red, coarse-grained granite columns, relatively small white marble columns and limestone blocks [4, 5].

Furthermore, the mosque of Al-Nasir Mohammed provides an important example of reusing the architectural elements dated back to previous old periods, as the granitic columns were brought from the archaeological and architectural elements of earlier Pharaonic constructions at Ashmunin in Upper Egypt. They were used to bear and support the arches of the inner arcades of the mosque $[6,7]$. During the Ottoman period, the mosque was highly deteriorated and lost some of its original architectural elements. In 1882 A.D., it was used as a prison and military store. In 1947, the mosque was restored by the committee for the conservation of Arab antiquities, and in 1983 it was restored by the supreme council of antiquities [1]. Due to the open courtyard of the mosque, the granitic columns are exposed to aggressive physiochemical and mechanical weathering processes that caused many damage aspects (Fig. 3) such as granular disintegration, scaling, cracking, efflorescence and soiling [813]. In addition, the granitic columns have suffered from the works of faulty restoration, as the columns were coated with inappropriate resinous material. Unfortunately, this unknown resinous material has been submitted to ageing processes which caused many deterioration aspects on the granitic columns such as color change, loss of aesthetical properties, accumulation of dust and microbiological colonization. (Fig. 4). 


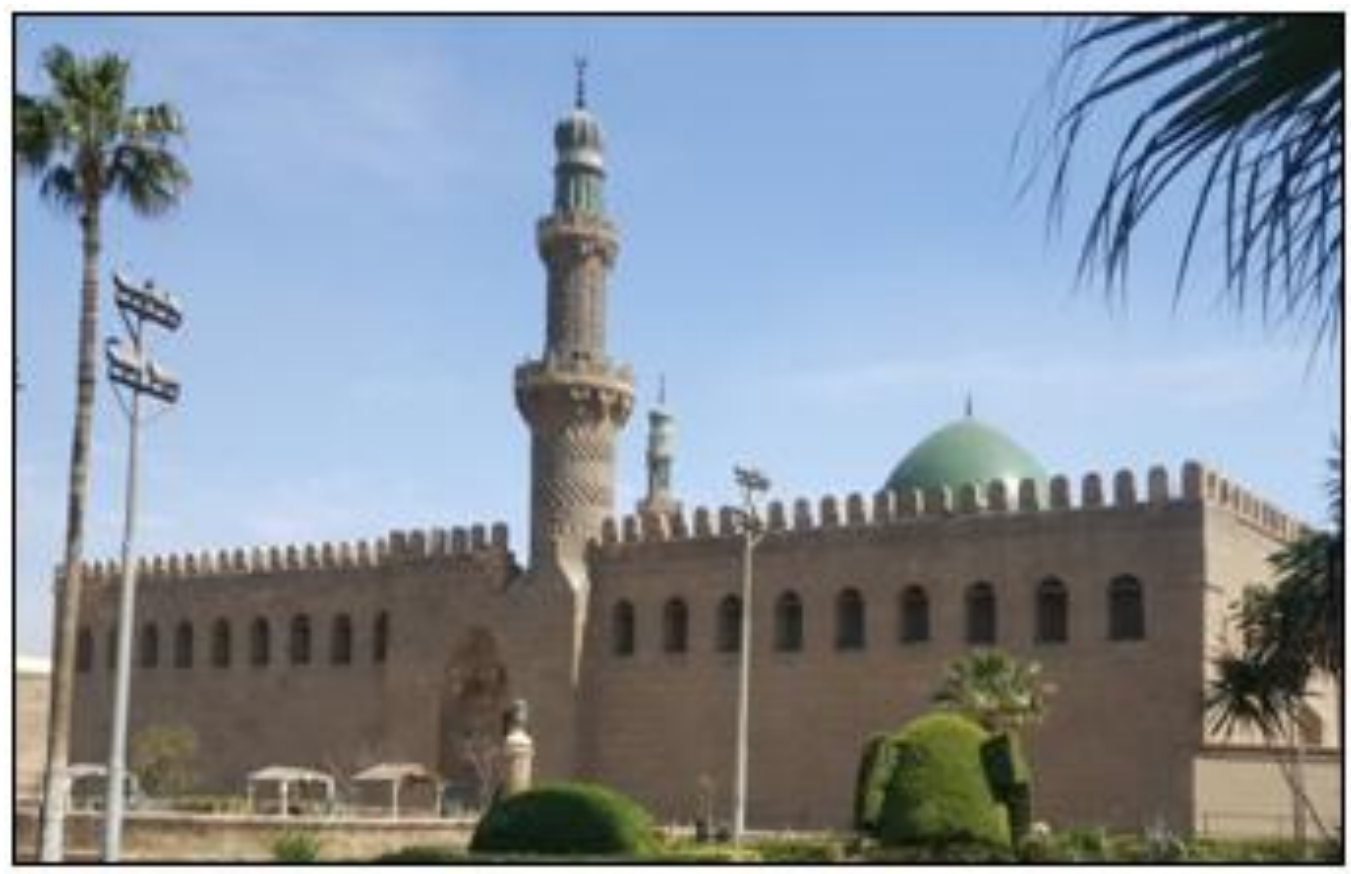

Fig. 1: The mosque of Al-Nasir Mohammad Ibn Qalawun.

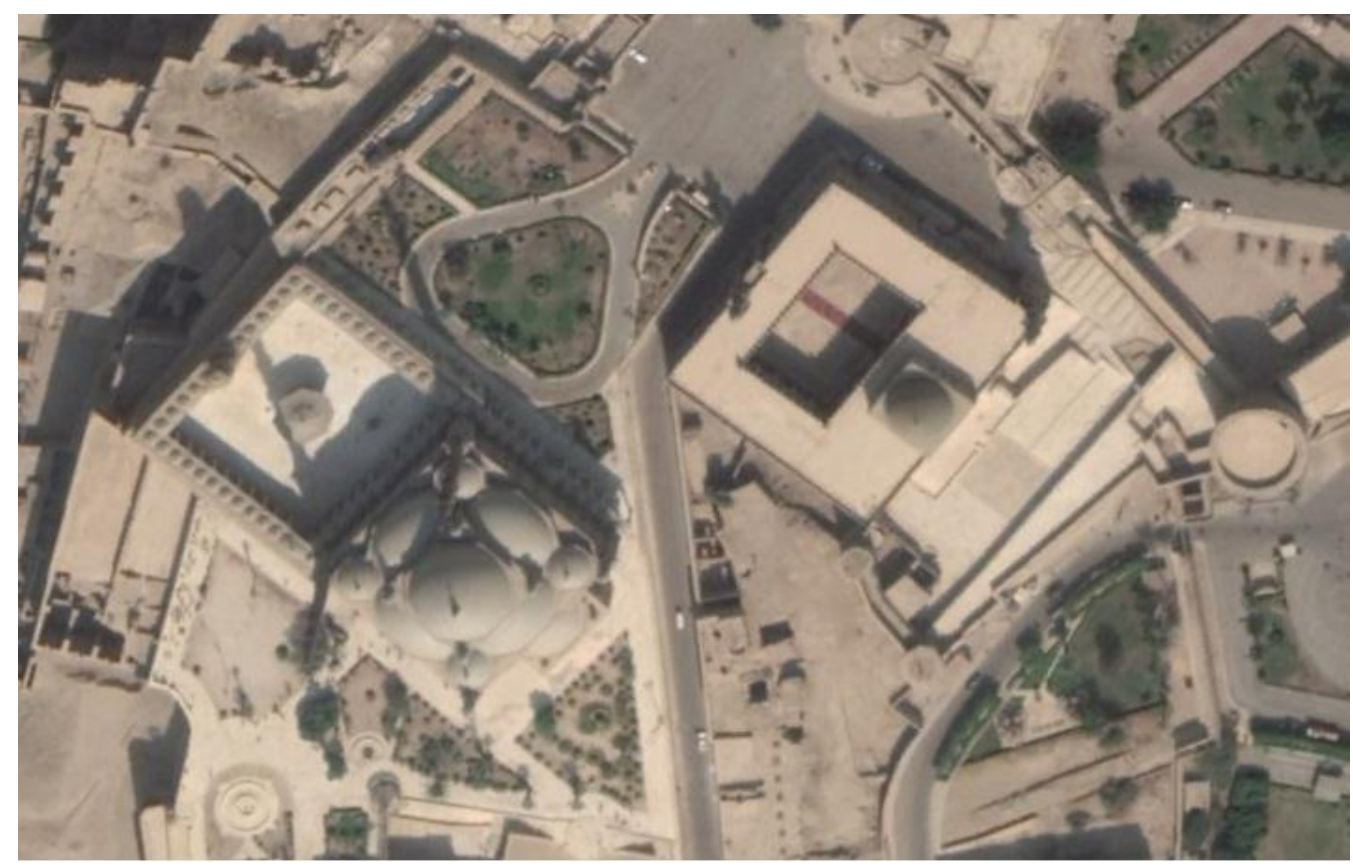

Fig. 2: The site of Al-Nasir mosque at Saladin citadel. (After: Google Earth). 


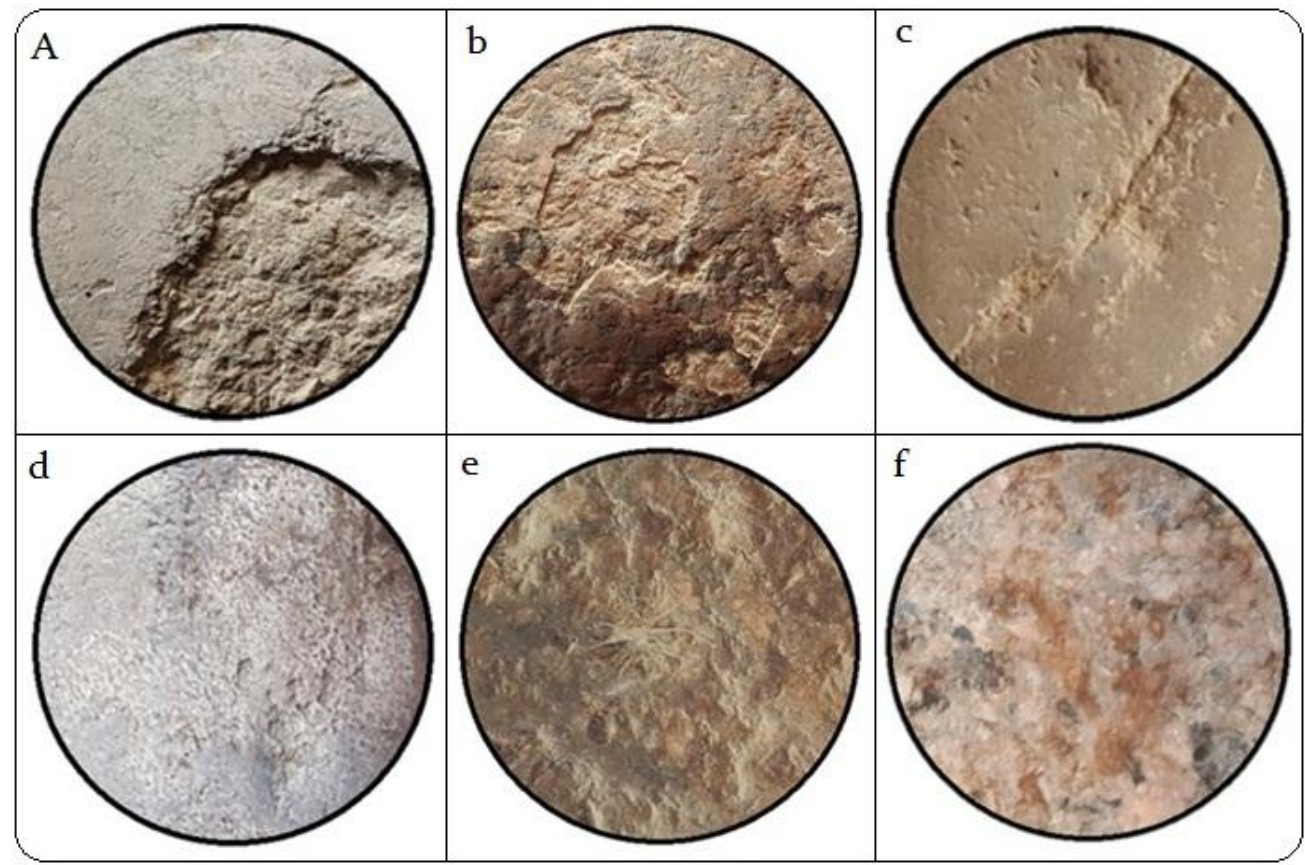

Fig. 3. Deterioration aspects of the studied granitic columns. (a, b) scaling and granular disintegration of surficial layer at the lower parts of the granitic columns; (c) cracks and pits at the lower parts; (d) salty layer, pits and voids; (e) deposition of soot and dust on the surface; (f) spots of hematite.
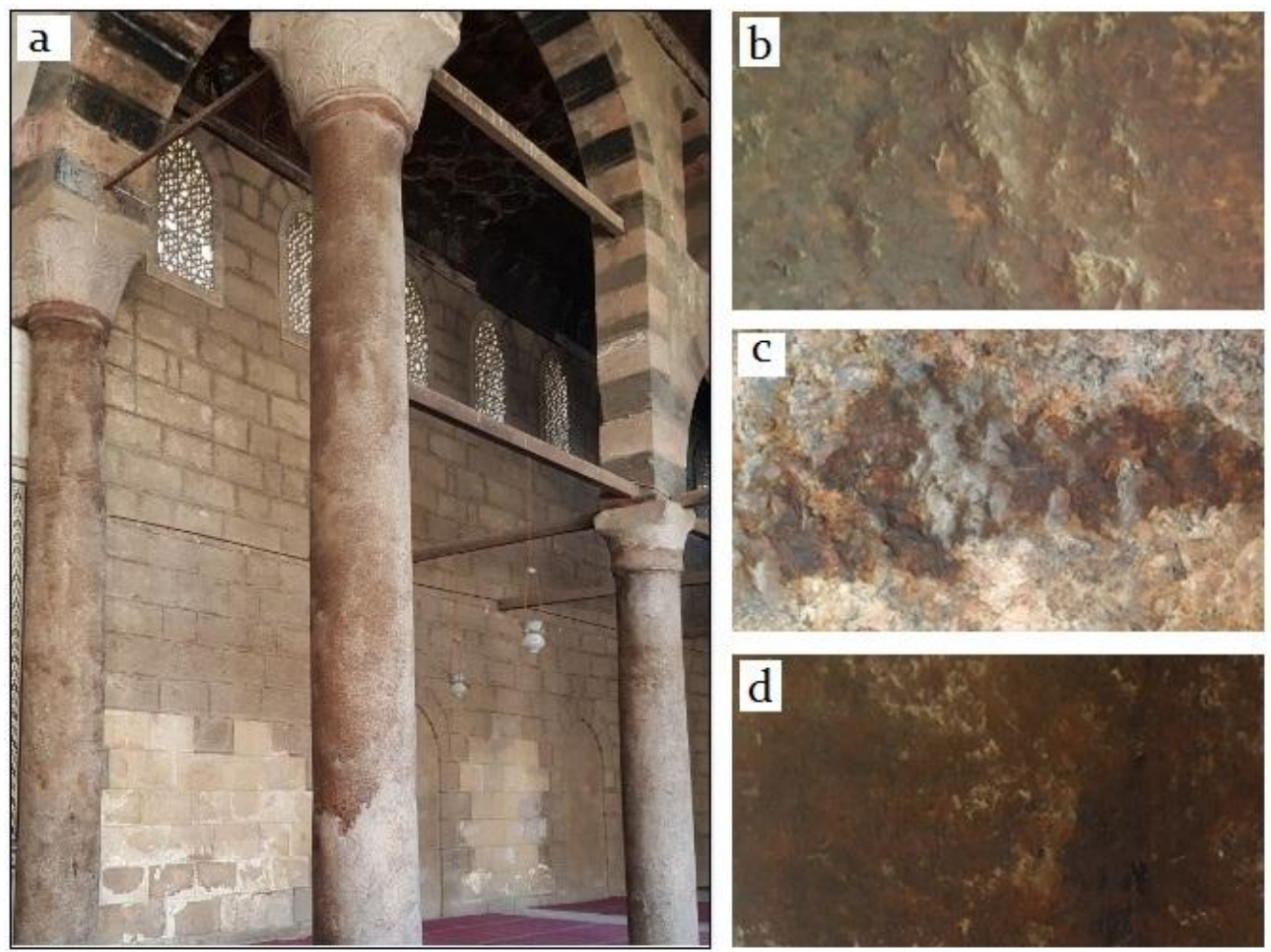

Fig.4. (a) Inappropriate resinous material applied on the surfaces of granitic columns; (b, c, d) damage aspects of resinous material. 
The present work deals with a special case of reused Pharaonic granitic columns. Rare researches could be found dealing with deterioration aspects of reused granitic columns inside archaeological mosques. It is the first analytical study of resinous materials previously applied on Egyptian granitic monuments. The main purpose of this work is to study the granitic columns and to characterize their deterioration aspects. Examinations and analytical study were carried out using stereomicroscope, scanning electron microscope, polarized light microscope, $\mathrm{X}$-ray diffraction analysis, energy dispersive spectrometer, Brunauer-EmmettTeller surface area, Raman spectroscopy and microbiological investigation.

\section{Materials and Methods}

\subsection{Materials}

\subsubsection{Sampling}

Small granitic samples were collected from the fallen fragments of the studied columns. Also micro samples were carefully taken from different locations of the weathering crusts.

\subsection{Methods}

\subsubsection{Stereomicroscope (SM)}

Stereomicroscope (Leica M165 C, France) was used to investigate the morphology and microstructure of the granitic samples in addition to their deterioration aspects. The samples were studied under stereomicroscope that can magnify the samples up to 120 times.

\subsubsection{Scanning electron micro- scope (SEM)}

The morphological aspects of granitic samples were examined by scanning electron microscope: model Quanta 250 FEG (field emission gun) with accelerating voltage $30 \mathrm{k} . \mathrm{V}$., magnification $14 \mathrm{x}$ up to 100000 and resolution for gun. 1 nm, FEI company, Netherlands.

\subsubsection{Polarized light microscope (PLM)}

Nikon eclipse LV100POL polarized light microscope was used to perform the petrographic study of the granitic samples. The samples were firstly consolidated with an epoxy resin, then they were cemented to glass slides, and finally were polished to become in the form of thin sections with thickness about 30 microns.

\subsubsection{X-ray diffraction analysis (XRD)}

In this study, X-ray diffraction analysis was used to identify the mineralogical composition of the granitic columns, in addition to study of their weathering products. The analysis was achieved using Philips Analytical X-Ray Diffractometer, with the following operating conditions:-

Diffractometer type: PW1840, Tube anode: $\mathrm{Cu}$, Generator tension $(\mathrm{Kv})$ : 40 , Generator current (mA): $25, \lambda \alpha 1(\AA)$ : $1.54056, \lambda \alpha 2(\AA): 1.54439$, Intensity ratio $(\alpha 2 / \alpha 1)$ : 0.500 , Receiving slit: 0.2 , Monochromator used: No.

\subsubsection{Energy dispersive spectrome- ter (EDS)}

The chemical analysis of the granitic samples was performed using the energy dispersive spectrometer (EDS) connected to Quanta 250 FEG scanning electron microscope, FEI company, Netherlands. EDS was calibrated using manganese oxide.

\subsubsection{BET technique}

Specific surface area of granitic samples was estimated based on the technique of Brunauer-Emmett-Teller (BET) using instrument of Quantachrome Touchwin 
v1.2 after degassing under N2 flow for $18 \mathrm{~h}$ at $90^{\circ} \mathrm{C}$.

\subsubsection{Raman spectrometer (RS)}

Raman spectrometer was employed to identify the nature of the resinous material that was previously applied on the surface of the studied granitic columns. Raman spectroscopy was carried out using LabRAM HR Evolution Raman spectrometer (HORIBA Jobin Yvon Technology, France). This instrument is equipped with a diode laser with laser wavelength of $532 \mathrm{~nm}$, and neutral density filter laser intensity $25-50 \%$. In order to validate the homogeneity of the samples, at least three measurements (for each sample) were recorded using objective lens $50 \mathrm{x}$. Raman spectra were recorded with power of $50 \mathrm{~mW}$ at wavenumber region between 200 and $1600 \mathrm{~cm}^{-1}$.

\subsubsection{Microbial investigation}

In order to identify the microbial strains that colonize the studied granitic columns, the samples were cultivated on two sterilized media (nutrient agar and Czapeck-Dox media). The first one was prepared for the culturing of bacteria while the second one was used for the culturing of fungi. Media plates were incubated at $30^{\circ} \mathrm{C}$ for seven days. After the incubation period (7 days), the growth of microorganisms (fungi and bacteria) became apparent, then the microbial strains were isolated and transferred to fresh plates for the selection of pure colonies. Finally, the pure colonies of fungi and bacteria were identified by optical microscope.

\section{Results and Discussion}

\subsection{Stereo investigation}

For the purpose of initial assessment of the studied granitic columns, samples were inspected by means of stereomicro- scope. The stereo micrographs (Fig. 5) show significant deterioration aspects in the granitic samples. The grains appear to be suffered from granular disintegration, flaking off, tiny cracks, pits and color alteration. Biotite grains are highly weathered, as they have many surficial deformation aspects. In addition, there is accumulation of weathering products on the grains surfaces, also in the pits and voids between the grains. In addition, the granitic samples lost their aesthetic properties, as the grains have been covered by the resinous matrix filled with soot and dust. Furthermore, the stereo micrographs declare the spreading of microbiological colonization, especially on the resinous material.

\subsection{Morphological study}

From SEM micrographs (Fig. 6), it can be clarified that the studied granitic columns were putted through hard weathering processes, as the samples appear to be very fragile and have a lot of voids, microcracks, etch-pits, salts, fungal colonization and tiny particles of weathering products (especially clay minerals).

\subsection{Petrographic characterization}

Petrographic characterization represents a very important step to obtain specific information and details about the studied granitic columns, which contribute in evaluation of their physical and mechanical properties. The study of petrographic micrographs of the studied granite (Fig. 7) suggests that its origin from Aswan. The data reveals the following points:-

- The samples are mainly composed of quartz $\mathrm{SiO}_{2}$, potash feldspars $\mathrm{KAlSi}_{3} \mathrm{O}_{8}$ (microcline and orthoclase) and plagioclase feldspars (albite $\mathrm{NaAlSi}_{3} \mathrm{O}_{8}$ and oligoclase $\left.[\mathrm{Na}, \mathrm{Ca}][\mathrm{Si}, \mathrm{Al}]_{4} \mathrm{O}_{8}\right)$ associated with small amounts of biotite $\mathrm{K}\left(\mathrm{Fe}^{+2}\right.$, $\mathrm{Mg})_{3}\left(\mathrm{AlSi}_{3} \mathrm{O}_{10}\right)(\mathrm{OH})_{2}$ and horn- 

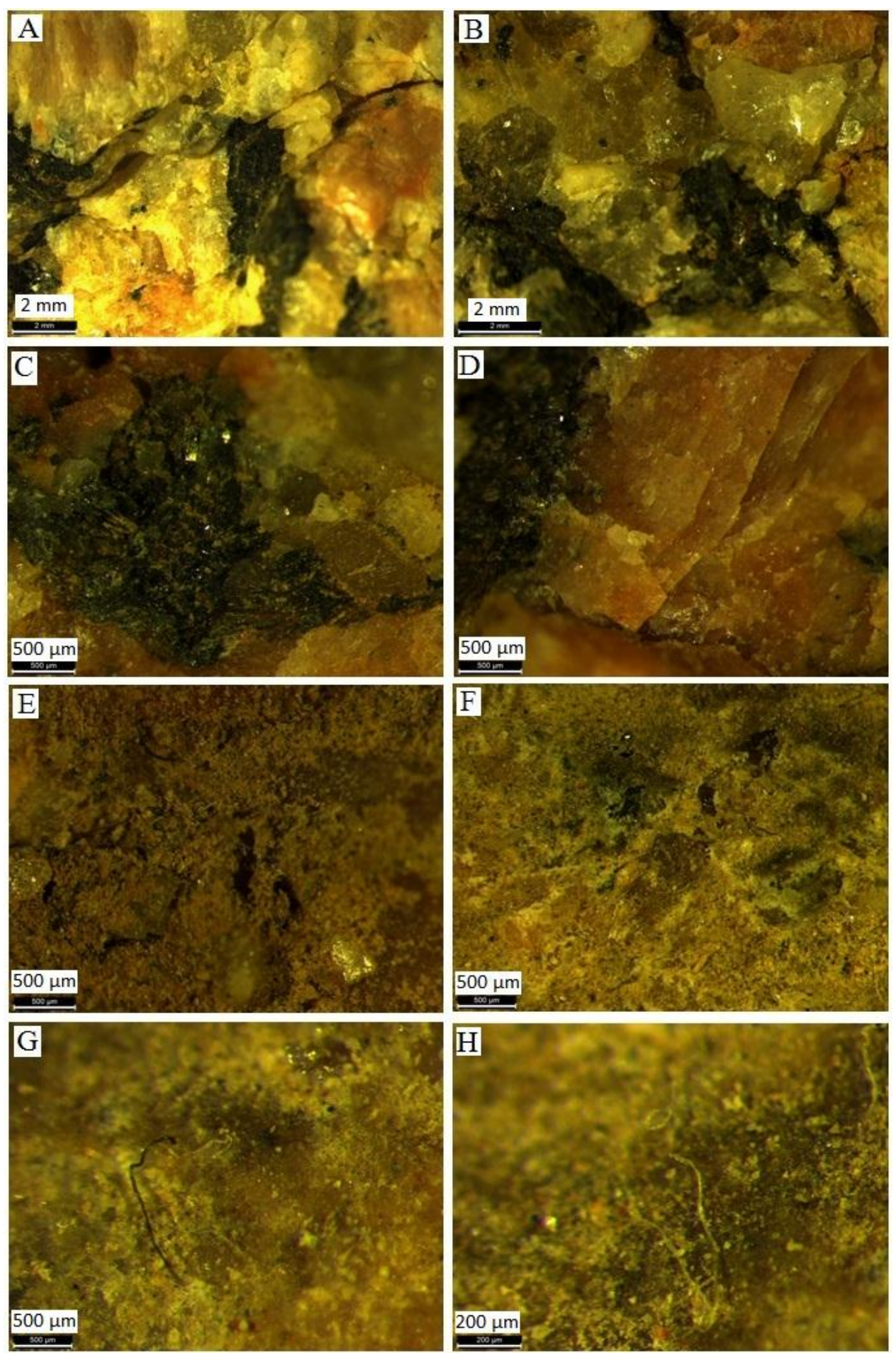

Fig.5. Stereo micrographs of granitic samples. (A, B) impact of mechanical deterioration that is represented in tiny cracks and granular disintegration, (c) trapping of weathering products in the pits and voids of altered and highly deformed biotite, (D) cleavage and microckracks of potash feldspar, (E, F) covering of granitic grains by resinous material mixed with dust particles, $(\mathrm{G}, \mathrm{H})$ spreading of microorganisms over the resinous material. 

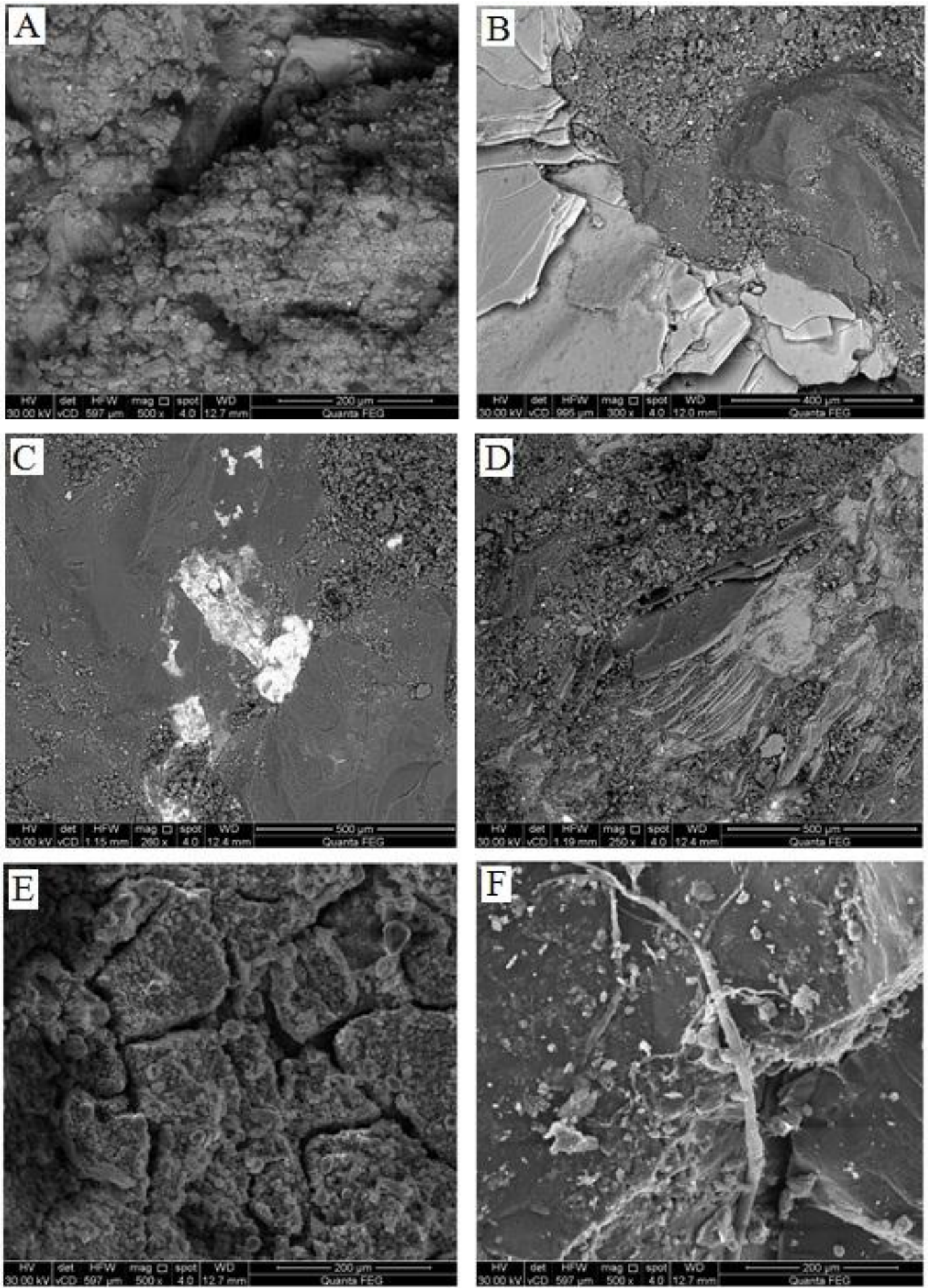

Fig. 6. SEM micrographs of the studied granitic samples. (A) granular disintegration, voids and mineralogical alteration aspects [500x]; (B) tiny cracks and surficial flaking [300x]; (C) crystallization of salt on the grain surface [260x]; (D) etching pits and clay minerals [250x]; (E) resinous material filled with tiny cracks [500x]; (F) spreading of fungal colonization between and over the grains $[500 x]$. 

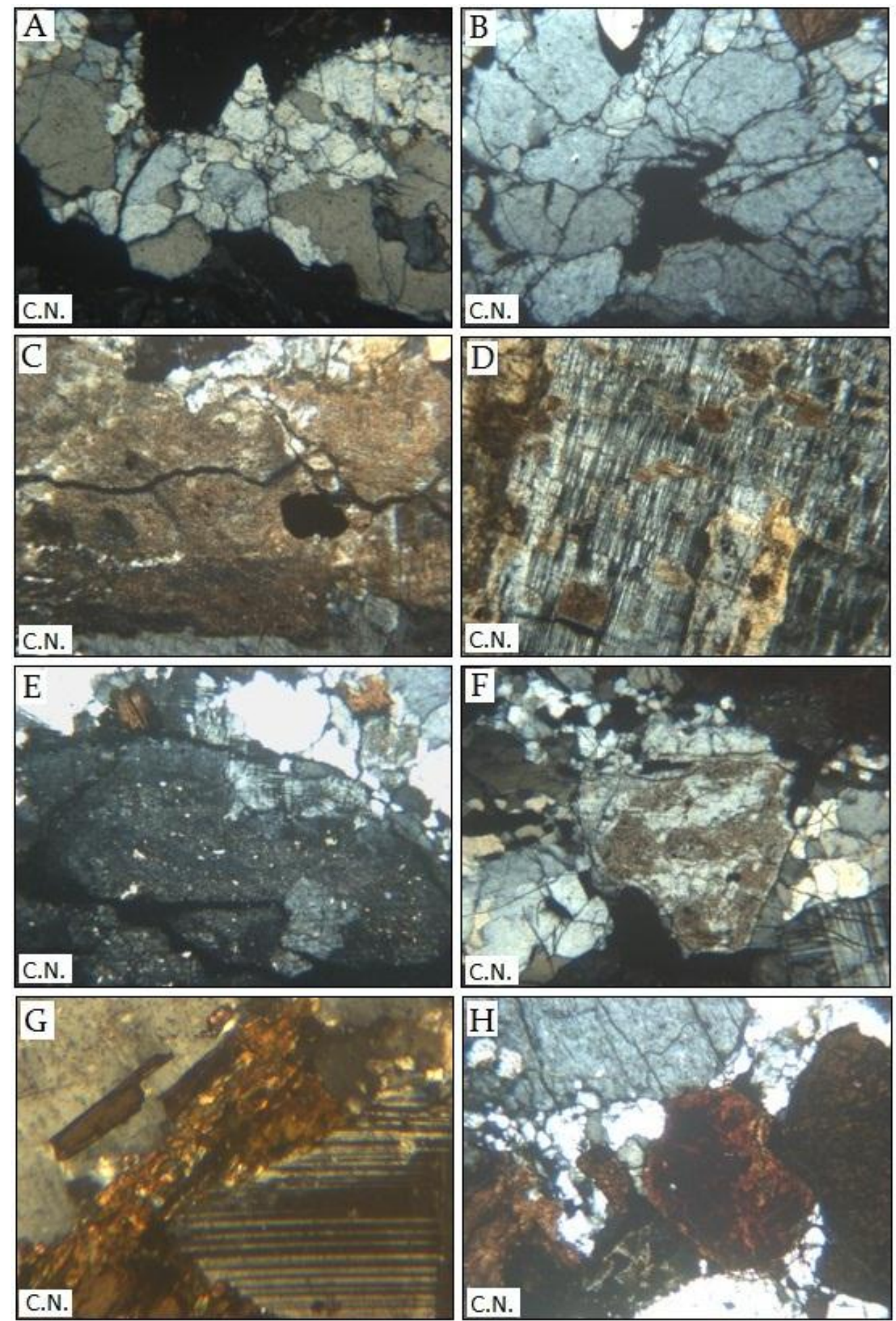

Fig.7. PLM micrographs of the studied granitic samples. (A, B) highly fractured quartz grains; (C) high alteration of orthoclase into sericite and clay minerals; (D) partial alteration of microcline into sericite and clay minerals (E, F) plagioclase grains suffer from slight and partial alteration to clay minerals; (G) plagioclase feldspar and deformed biotite; $(\mathrm{H})$ high alteration of biotite into hematite. (Magnification $25 \mathrm{X}$ ). 
blende $\mathrm{Ca}_{2} \mathrm{Na}(\mathrm{Mg}, \mathrm{Fe})_{4}(\mathrm{Al}, \mathrm{Fe}$, $\mathrm{Ti})(\mathrm{AlSi})_{8} \mathrm{O}_{22}(\mathrm{O}, \mathrm{OH})_{2}$.

- Quartz represents an essential mineral constituent that occurs as fine to medium-grained, anhedral crystals. It also exists as crystal aggregates between feldspar crystals. Some quartz grains has sutured, fractured and curved boundaries while others are granulated. Although quartz possesses high degree of durability, it is highly affected by cracks and fractures. High deformation of quartz clarifies the high mechanical stresses to which the granitic columns are subjected since the Pharaonic period up till now.

- Potash feldspars are the most abundant constituents in the samples. They are characterized by crosshatching and simple twinning, respectively. They are medium to coarse-grained, generally subhedral to anhedral crystals. They appear to be partially or highly altered to sericite $\mathrm{KAl}\left(\mathrm{AlSi}_{3} \mathrm{O}_{10}\right)(\mathrm{OH})_{2}$ and clay minerals (hydrated aluminum silicate), which reflect the high impact of physiochemical weathering on the granitic minerals. In addition, the effect of weathering processes on the granitic minerals are reflected in their mechanical properties, as the grains appear containing many microcracks and surficial deformation.

- Plagioclase feldspars are medium to coarse-grained, showing distinct lamellar twinning. Also, plagioclase feldspars interfere with microcline, composing perthitic texture. They are partially and highly altered to clay minerals and present as irregular lamellae.

- Biotite occurs in minor amount as fine to medium-grained, tabular, flaky crystals between feldspars and quartz. Due to physiochemical and mechanical weathering processes, biotite grains suffer from surficial deformation and microcracking. It is converted to reddish brown hematite $\left(\mathrm{Fe}_{2} \mathrm{O}_{3}\right)$.

- Hornblende occurs as a minor constituent, it presents as fine to medium-grained aggregates, prismatic crystals associated with biotite. It is slightly to highly altered to hematite.

- The high content of mineralogical alteration of feldspars to clay minerals illustrates the reason of grey color layers formed on the surface of studied granitic columns.

\subsection{Mineralogical composition}

The physical and mechanical properties of stones mainly depend on their mineralogical compositions. Therefore, it is very important to identify the mineralogical composition of the studied granitic columns. This identification provides a semi quantitative evaluation of the constituting minerals and weathering products. For this purpose, the mineralogical composition of the studied granitic columns was determined using x-ray diffraction analysis.

X-ray diffraction pattern (Fig. 8) reveals that the studied granite is mainly composed of quartz (30.2\%), microcline $(21.2 \%)$, orthoclase $(6 \%)$, albite $(13.3$ $\%)$, oligoclase $(10.1 \%)$, biotite $(3.1 \%)$ 


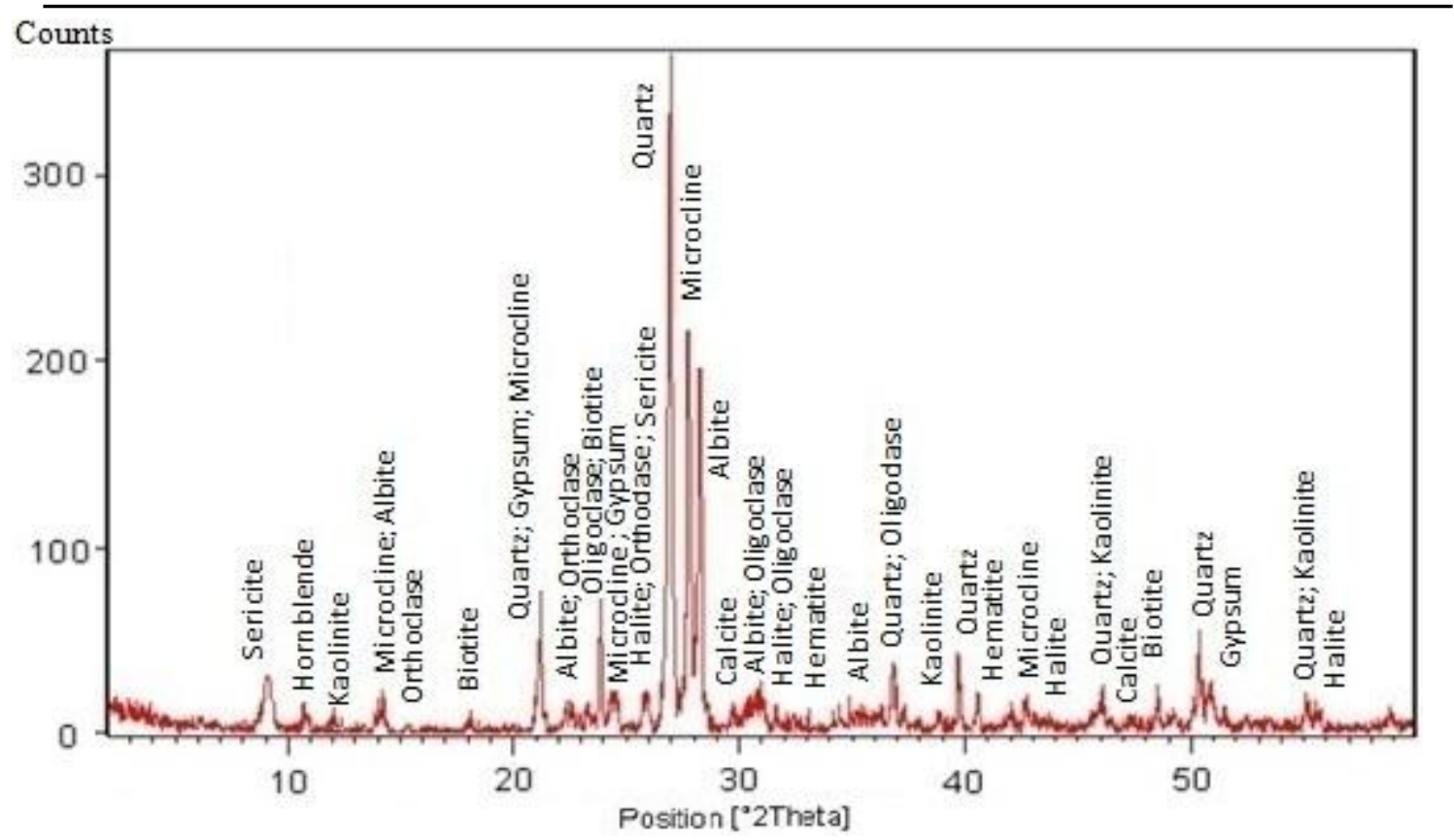

Fig. 8. X-ray diffraction pattern of the studied granitic sample.

and hornblende $(2.1 \%)$. On the other hand, sericite $(2.3 \%)$, kaolinite $(2.2 \%)$, calcite $(2 \%)$, gypsum $(3.2 \%)$, halite (2 $\%)$ and hematite $(2.3 \%)$ are detected as weathering products. Presence of the previously mentioned secondary minerals reflects the hard physiochemical weathering processes affecting the studied granitic columns. Water (from the different resources such as rain, relative humidity, ground water) and atmospheric pollutions (such as $\mathrm{CO}_{2}, \mathrm{SO}_{2}, \mathrm{NO}_{\mathrm{x}}$ ) are the main factors of physiochemical weathering. The high rates of fossil fuel combustion related to the urban and industrial developments, led to increasing the concentrations of carbon dioxide, sulphur dioxide and nitrogen oxides. The dissolving of these gases in water giving rise to the formation of acidic solutions, which play the significant role in mineralogical alteration of granite [14]. The formation of sericite in the granitic columns is attributed to the hydrolysis of potash feldspars and biotite, which finally causes their mineralogical alteration [15].
In addition, kaolinite is formed due to the alteration of feldspars and biotite in later stage of physiochemical weathering [16]. Calcite is formed due to the reaction between carbonic acid and Ca-bearing feldspars [17]. Moreover, it can be suggested that the formation of gypsum in the studied columns is a result of the reaction between sulfuric acid and Ca-bearing feldspars [18]. Halite can arise on granite surface from subsoil water rich in sodium and chlorine. Also, it probably occurs as a result of the reaction between chlorine anions (from different sources) and sodium ions in Na-bearing feldspars. On the other hand, the presence of hematite is ascribed to the leaching of iron from the crystal structure of biotite at the early stage of weathering processes. Oxidation of ferrous ions to ferric ones forming hematite stains on microfracture cleavages [15].

However, granitic rocks possess high resistance and durability against deterioration; they can be highly affected by weathering processes related to the open environment. Weathering processes at- 
tack the primary minerals of granite such as feldspars and micas, and finally alter them into secondary, low resistant and weak minerals such as clay minerals and hematite [14]. The mineralogical alteration of the granitic minerals into clay minerals is considered the main degradation step that turns durable granite into an easily degradable stone. This is can be assigned to the substantial role of mineralogical alteration in accelerating the mechanical weathering processes. Since the formation of clay minerals takes place in the surficial layer of the granitic stones, this layer is usually exposed to mechanical deterioration aspects such as granular disintegration, cracking and scaling [19].

\subsection{Chemical analysis by EDS}

Data obtained from the chemical analysis of a weathered granitic sample (Table. 1), confirms the presence of some weathering products previously detected by XRD analysis. The elements of calcium, carbon, sulphur and oxygen indicate the presence of calcite and gypsum. Furthermore, the appearance of chlorine in the chemical composition declares the presence of halite. The high percentage of iron reflects the high alteration of biotite and hornblende to hematite.

Furthermore, a granitic sample taken from the parts covered with resinous material, was chemically analysed by EDS. The results (Table. 2) suggest that the resin applied on the granitic columns is turpentine, as the sample contains relatively high percentage of sulfur element. Sulphur compounds are formed in turpentine as a by-product of the kraft and sulfate pulping processes, which have been widely used in production of turpentine since 1970 [20, 21].
In the past, turpentine was commonly applied on the Egyptian granitic monuments in order to preserve their glossy and polished appearance. This aspect of fault restoration occurred when conservation works were entrusted to nonspecialist persons or contractors.

\subsection{Specific surface area}

Specific surface area of granite is defined as the total surface area of pores per unit of bulk volume. In this study, the technique of BET was used to evaluate the outer surface of the studied granitic columns [13, 22, 23].

Two deteriorated samples were comparatively studied with a fresh granitic sample collected from the granite quarry of Aswan. The results of specific surface area are reported in Table. 3. It is well known that granite has interlocked texture and very low porosity, this is due to its nature as an igneous rock.

Despite the above mentioned properties of granite, the studied granitic samples show high specific surface areas which consequently reflect their high levels of porosity. High porosity in the studied granite is a result of weathering processes, which led to the formation of porous and fractured surficial network [24]. In addition, this porous network allows water (from any source) to permeate and transfer through the outer deteriorated layer, and thus catalyzing the physiochemical and microbiological deterioration factors. The mechanical deterioration aspects (such as disintegration, cracking and scaling) are formed as a final result of physiochemical and microbiological weathering [25-28]. 
Advanced Research in Conservation Science, Vol. 1, No. 1, 2020, 34-51

\begin{tabular}{cc}
\hline $\begin{array}{c}\text { Table 1. EDS results: chemical composition of a weathered granitic } \\
\text { sample. }\end{array}$ \\
\hline Main elements & Concentration (wt \%) \\
\hline $\mathrm{C}$ & $04.84 \pm 0.09$ \\
\hline $\mathrm{O}$ & $32.11 \pm 0.64$ \\
\hline $\mathrm{Na}$ & $01.45 \pm 0.02$ \\
\hline $\mathrm{Mg}$ & $02.27 \pm 0.04$ \\
\hline $\mathrm{Al}$ & $06.36 \pm 0.12$ \\
\hline $\mathrm{Si}$ & $22.56 \pm 0.45$ \\
\hline $\mathrm{P}$ & $00.75 \pm 0.01$ \\
\hline $\mathrm{S}$ & $02.68 \pm 0.05$ \\
\hline $\mathrm{Cl}$ & $00.66 \pm 0.01$ \\
\hline $\mathrm{K}$ & $04.09 \pm 0.08$ \\
\hline $\mathrm{Ca}$ & $04.64 \pm 0.09$ \\
\hline $\mathrm{Ti}$ & $02.28 \pm 0.04$ \\
\hline $\mathrm{Fe}$ & $15.31 \pm 0.13$ \\
\hline
\end{tabular}

Table 2. EDS results: chemical composition of a granitic sample covered with resinous material.

\begin{tabular}{cc} 
Main elements & Concentration (wt \%) \\
\hline $\mathrm{O}$ & $63.00 \pm 1.26$ \\
\hline $\mathrm{Ca}$ & $21.00 \pm 0.42$ \\
\hline $\mathrm{S}$ & $10.00 \pm 0.20$ \\
\hline $\mathrm{C}$ & $04.20 \pm 0.08$ \\
\hline $\mathrm{Si}$ & $00.80 \pm 0.01$ \\
\hline $\mathrm{Fe}$ & $01.00 \pm 0.02$ \\
\hline
\end{tabular}

Table 3. Results of specific surface area of granitic samples.

\begin{tabular}{cc}
\hline Sample & Specific Surface Area $\left(\mathbf{m}^{2} / \mathbf{g}\right)$ \\
\hline Fresh sample & 02.50 \\
\hline Moderately weathered sample & 08.85 \\
\hline Highly weathered sample & 22.30 \\
\hline
\end{tabular}




\subsection{Spectroscopic study}

The lack of knowledge about the traditional materials used in the earlier restoration works, is considered to be one of the most affective obstacles in the field of conservation [29]. Doubtless, the detailed information about the monuments and archaeological objects and their previous restoration works plays a substantial role in performing correct plan for future conservation procedures. Raman spectroscopy is a powerful laser spectroscopy technique which has been applied in the field of conservation to provide molecular information about organic and inorganic components of the archaeological and restoration materials [30]. In this study, Raman spectroscopy was used to determine the resinous material applied on the studied granitic columns.

By studying the databases of Raman analysis that have been established by previous studies [31], it can be seen that the spectra of studied resin includes the same main characteristic bands as terpenoid, especially turpentine. Therefore, Raman spectra of the studied resin is compared with the spectrum of turpentine that is widely used in the restoration works at Egyptian archaeological sites. The comparative study clarifies that the compared samples are highly similar, as their Raman bands are observed in the same positions, as seen in Fig. 9. The bands in the region between 1480 and $950 \mathrm{~cm}^{-1}$ can be attributed to $\delta(\mathrm{CH})$, $\delta\left(\mathrm{CH}_{2}\right)$ and $\delta\left(\mathrm{CH}_{3}\right)$ deformations and $v(\mathrm{CC})$ stretching vibrations [31]. The difference between the studied resin spectra and the reference spectra of turpentine sample could be due to the impact ageing processes on the studied resin [30, 32].

\subsection{Microbiological study}

Microbiological study of granitic samples showed high density of fungal and bacterial growth. Two types of fungi (Aspergillus niger and Penicillium sp.) and one type of bacteria (Bacillus sp.) were identified by optical microscope (Fig. 10). The growth of microorganisms on granitic stones led to physical, chemical and mechanical degradation aspects. They caused undesirable aesthetical alterations of outer surfaces of granite. In addition, they produced high amounts of organic acids that accelerate the alteration of feldspars into clay minerals [13]. What's more, they contributed to the mechanical damage of granite due to the pressure associated to their growth inside the pores and beneath decomposed layers $[11,13]$.

\section{Conclusion}

The studied granitic columns were transported from earlier Pharaonic monuments in Upper Egypt and reused in construction of the mosque of Al-Nasir Mohammad Ibn Qalawun in 1318 A.D. Although, the columns were submitted to weathering processes during the Pharaonic period, they probably were in good state, as the Islamic architects avoided reusing the deteriorated stones in their constructions. It can be suggested that the aggressive physiochemical damage of the studied columns took place in the last two centuries. This is due to the high rates of air pollutants in addition to the humid environment in Lower Egypt. Furthermore, the columns had undergone to faulty restoration practices in the recent years. 


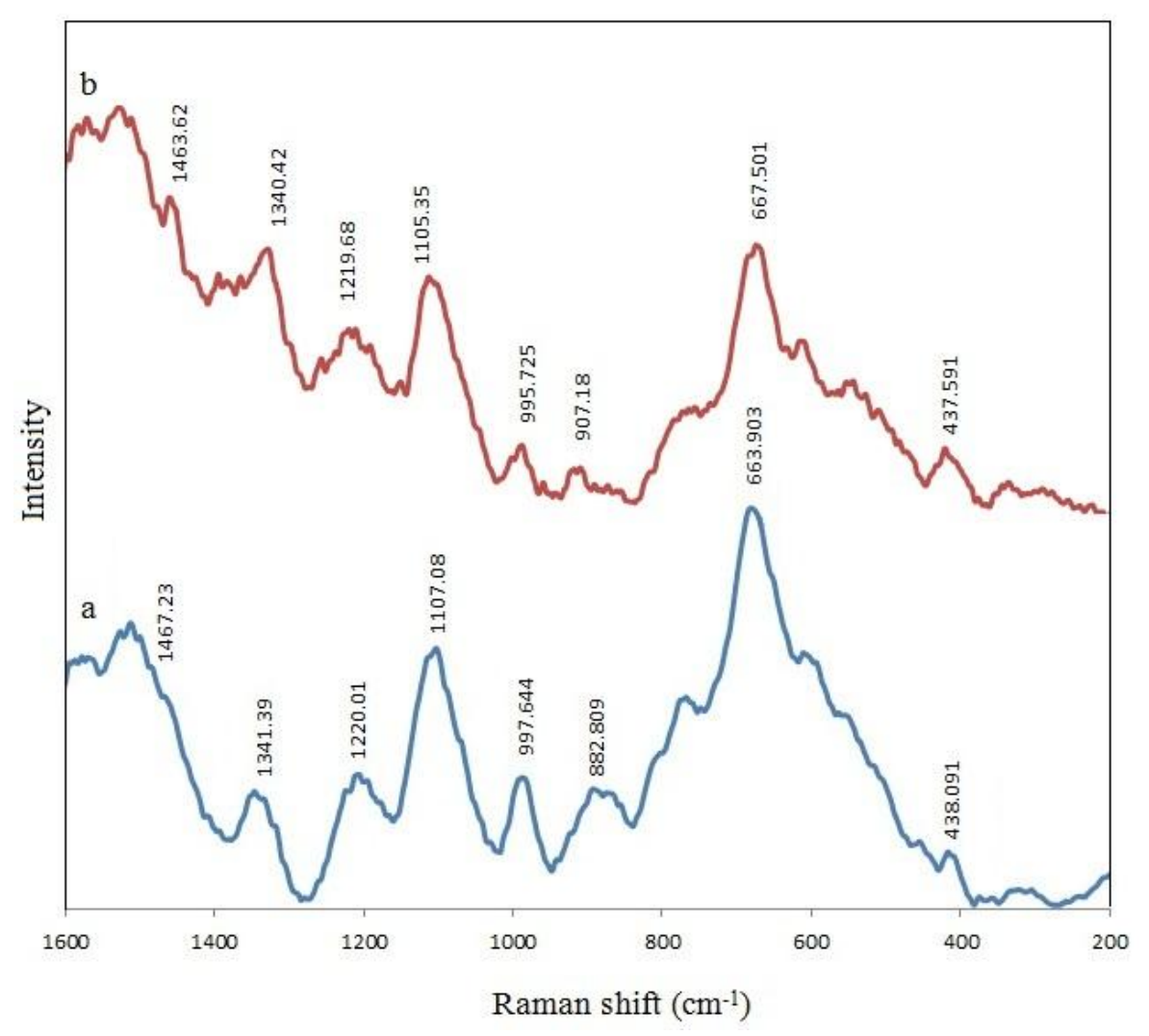

Fig. 9: Raman spectra of (a) Turpentine reference sample, and (b) resinous material on granitic columns.
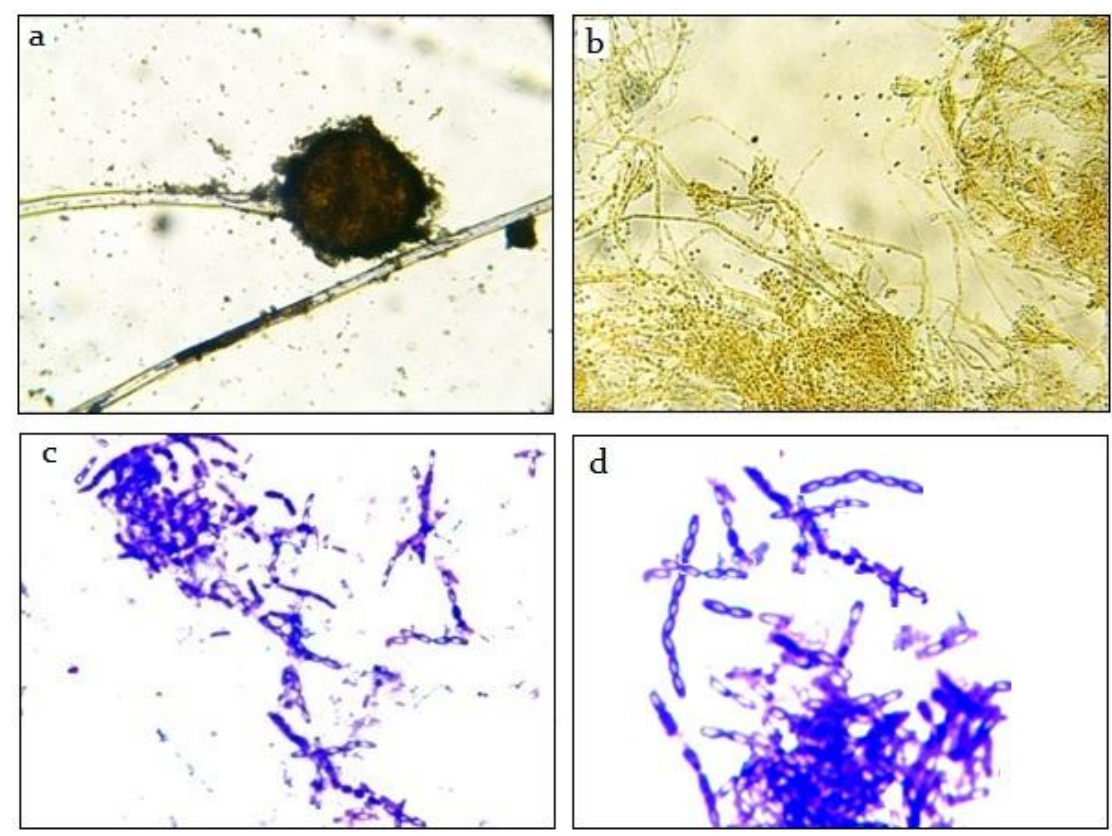

Fig.10: Optical micrographs of (a) Aspergillus niger; (b) Penicillum sp.; (c, d) Bacillus sp. 
Based on the obtained results, the studied granitic columns have highly suffered from physiochemical weathering processes that caused the conversion of original minerals into secondary ones. Kaolinite, sericite, calcite, gypsum, halite and hematite were detected as secondary weathering products. The formation of clay minerals on the surficial layers of the granitic columns have played an essential role in accelerating the mechanical deterioration aspects, such as granular disintegration, surficial deformation, cracking and flaking. Specific surface areas of the granitic samples reflected their high levels of porosity resulting from hard weathering processes.

Moreover, the resinous material coating the granitic columns led to color alteration, loss of aesthetic properties, accumulation of dust and microbiological colonization. Microbiological investigation declared the presence of Aspergillus niger, Penicillium sp., and Bacillus sp. on the granitic columns, especially in the places treated with resinous material.

The proposal for treatment and conservation of the studied granitic columns includes the following points (after carrying out experimental work):-

- Preventing the source of subsoil water by gradually minimizing its level.

- Desalination of halite using a suitable poultice.

- Inhibition the growth of microorganisms by utilizing antifungal and antibacterial nanomaterials.

- Removing the turpentine layer using smart materials such as nanomagnetic gels.

- Consolidation and protection by application of superhydrophobic, selfcleaning nanocomposites and/or biopolymers.

\section{Acknowledgements}

The authors would like to thank Dr. Ahmed Abd El-Kawy, associate professor of Islamic architecture at Misr University for Science and Technology, for his assistance during collecting the archaeological information about the studied mosque.

\section{References}

1. A. A. Ahmed, History and Archaeology of Islamic Egypt in the Ayyubid and Mamluk Periods, Egypt: Al-Hariri Publishing, 2007.

2. M. Kashef, "Bahri Mamluk muqurnas portals in Egypt: Survey and analysis", Frontiers of architectural Research, Vol. 6, 2017, pp. 487-503.

3. T. A. El-Akkad, "The Aesthetics of Islamic Architecture and the Exuberance of Mamluk Design", Ph. D. thesis, International University of Catalonia, Barcelona, 2013.

4. S. S. Blair and J. M. Bloom, The Art and Architecture of Islam: 12501800, New Haven: The Yale University Press, 1994.

5. D. Behrens-Abouseif, Cairo of the Mamluks: A history of Architecture and its Culture, Cairo: The American University Press, 2007.

6. C. M. Waston, "The mosque of Sultan Al-Nasir Mohammed Ebn Kalaoun", in the Citadel of Cairo, The Journal of the Royal Asiatic Society of Great Britain and Ireland, Vol. 18. No. 4, 1986, pp. 477-483.

7. N. O. Rabbat, The Citadel of Cairo: A new Interpretation of Royal Mamluk Architecture, Netherlands: E. J. Brill, 1995.

8. F. M. Helmi, "Deterioration of some granite in Egypt", In Proc. $5^{\text {th }}$ International Congress on Deterioration and Conservation of Stone, 1995, pp. 421-429.

9. A. La Iglesia, M. A. Garcia Del Cura, and S. Ordonez, "The physicochemi- 
cal weathering of monumental dolostones, granites and limestones: dimension stones of the cathedral of Toledo (Spain)", Science of The Total Environment, Vol. 152, 1994, pp. 179-188.

10. J. A. Baptista-Neto, B. J. Smith, J. McAllister, M. Silva, and S. Castanheira, "Surface modification of a granite building stone in central Rio de Janeiro", Anais da Academia Brasileira de Ciências, Vol. 78, 2006, pp. 317-330.

11. N. Wongfun, M. Plötze, G. Furrer, and H. Brandl, "Weathering of granite from the Damma glacier area: the contribution of cyanogenic bacteria", Journal of Geomicrobiology, Vol. 31, 2010, pp. 93-100.

12. Y. Kwon, and S. Oh, "Physical and mechanical properties of decomposed granite soils sampled in Cheongju, Korea", International Journal of the Physical Sciences, Vol. 6, No. 24, 2011, pp. 5777-5794.

13. R. G. Giménez, R. V. Mencia, I. S. Garcia, and J. C. Arribas, "Alteration processes of historical Granitic rock found in Avila, Spain", Mediterranean Archaeology and Archaeometry, Vol. 13, No. 1, 2013, pp. 107-115.

14. M. H. Ghobadi, and A. A. Momeni, "Assessment of granitic rocks degradability susceptive to acid solutions in urban area", Environmental Earth Sciences, Vol. 64, 2011, pp. 753-760.

15. F. M. Helmi, and Y. K. Hefni, "Nanocomposites for the protection of granitic obelisks at Tanis, Egypt", Mediterranean Archaeology and Archaeometry, Vol. 16, No. 2, 2016, pp. 87-96.

16. D. Gour, Ch. Soumendu, and D. Nilanjana, "Weathering and Mineralogical Alteration of granitic rocks in Southern Purulia District, West Bengal, India”, International Re- search Journal of Earth Sciences, Vol. 2, 2014, pp. 1-12.

17. A. A. El-Badry, "Environmental Degradation of Granite Stoneworks, Karnak Temples, Egypt", International Journal of ChemTech Research, Vol. 11, No. 9, 2018, pp. 340352.

18. N. Schiavon, "Kaolinisation of granite in an urban environment", Environmental Geology, Vol. 52, 2017, pp. 399-407.

19. M. Heidari, G. R. Khanlari, A. A. Momeni, and H. Jafargholizadeh, "The relationship between geomechanical properties and weathering indices of granitic rocks, Hamedan, Iran", Geomechanics and Geoengineering: An International Journal, Vol. 6, No. 1, 2011, pp. 59-68.

20. S. Masten, "Turpentine (turpentine oil, wood turpentine, sulfate turpentine, sulfite turpentine)", $\mathrm{Ph}$. D. thesis, National Institute of Environmental Health Sciences, North Carolina, 2002.

21. E. S. Izmest'ev, S. A. Rubtsova, and A. V. Kutchin, "Environmental aspects of sulfate turpentine refining (review)", Theoretical and Applied Ecology, No. 1, 2019, pp. 12-22.

22. S. O. Alayande, M. P. Mubiayi, M. E. Makhatha, and R. Derek, "Experimental characterization of physicochemical and geological properties of granite from Olowu, Ibadan, Oyo State, Nigeria", In Proc. The World Congress on Mechanical, Chemical, and Material Engineering, No. 337, 2015, pp. 1-9.

23. L. M. Anovitz, and D. R. Cole, "Characterization and analysis of porosity and pore structures", Reviews in Mineralogy and Geochemistry, Vol. 80, 2015, pp. 61-164.

24. M. Rosener, and Y. Geraud, "Using physical properties to understand the porosity network geometry evolution 
in gradually altered granites in damage zones", Geological Society of London, Vol. 284, 2007, pp. 175-184.

25. A. Begon, and M. A. Sequeria Braga, "Weathering of the Oporto granite: geotechnical and physical properties", Catena, Vol. 49, 2002, pp. 5776.

26. D. Haskin, Chemical and mineralogical weathering indices as applied to a granite saprolite in South Africa, Bulletin of the International Association of Engineering Geology, No. 465, 2006, pp.1-4.

27. B. Pereira de Oliveira, J. M. de la Rosa, A. Z. Miller, C. Saiz-Jimenez, A. Gomez-Bolea, M. A. Sequeira Braga, and A. Dionisio, "An integrated approach to assess the origins of black on a granite monument", Environmental Earth Sciences, Vol. 63, 2011, pp. 1677-1690.

28. G. Douli, S. Chatterjee, and N. Das Chatterjee, "Geophysical and geochemical alteration of rocks in granitic profiles during intense weathering in southern Purulia district, West Bengal, India", Modeling Earth Systems and Environment, Vol. 2, 2016, p. 132.
29. P. Vandenabeele, M. Ortega-Avil`es, D. T. Castilleros, and L. Moens, "Raman spectroscopic analysis of Mexican natural artists' materials", Spectrochimica Acta Part A, Vol. 68, 2007, pp. 1085-1088.

30. E. Casanova, Ch, Pele-Meziani, E. Guilminot, J. Mevellec, Ch, RiquierBouclet, A. Vinçotte, and G. Lemoine, "The use of vibrational spectroscopy techniques as a tool for the discrimination and identification of the natural and synthetic organic compounds used in conservation", Analytical Methods, Vol. 8, 2016, pp. 8514-8527.

31. P. Vandenabeele, B. Wehling, L. Moens, H. Edwards, M. De Reu, and G. Van Hooydonk, "Analysis with micro-Raman spectroscopy of natural organic binding media and varnishes used in art", Analytica Chimica Acta, Vol. 407, 2000, pp. 261-274.

32. A. Nevin, D. Comelli, I. Osticioli, L. Toniolo, G. Valentini, and R. Cubed$\mathrm{du}$, "Assessment of the ageing of triterpenoid paint varnishes using fluorescence, Raman and FTIR spectroscopy", Analytical and Bioanalytical Chemistry, Vol. 395, 2009, pp. 2139-2149. 